\title{
Contributors on Their Cosmopolitan Experiences: A Postscript
}

\section{Samir Dayal}

My interest in cosmopolitanism and related topics such as diaspora, immigration, transnationalism, hybridity, and even citizenship certainly has a personal dimension. I was born in India and have now lived longer in the United States than in the Subcontinent. My immediate family are now spread across three countries, and I have close family connections across several continents. Yet I have always been keenly sensitive to the hazard of unreflectively identifying oneself as, or claiming to be, "cosmopolitan," as if one had the luxury of being at home everywhere, just as I have often and long resisted a merely autobiographical-a predictable-interest in South Asian and postcolonial studies, domains in which I nevertheless now work and publish, though not exclusively. If people across the world are to be able to be interested in, to care for and be responsible for, one another, I believe that we need to think of ourselves as inhabiting a shared world: In that sense cosmopolitanism is socially and ethicopolitically defensible. So I would say I have had a complicated interest in both cosmopolitanism as an attitude of openness to the world and cultural difference, culturally specific self-fashioning, and subject-formation, from scholarly and personal perspectives.

\section{Taoufik Djebali}

I have a personal and an academic interest in cosmopolitanism. Indeed, I was born and raised in Tunisia, a former French possession in North Africa, known for its cohesion and ethnic homogeneity. In the 1980s, like many North African students, I decided to move to Paris to pursue higher education. After I got a degree in sociology and a Ph.D. in American studies on race and public policy, I started a career in teaching at the University of Caen in the northwest of France. Since then, I have been dividing my time between the port city of Caen and Paris, the French cosmopolitan city par excellence. For me, however, cosmopolitanism is not just a concept dealt with in the academia. It is also a cultural, a social, and a psychological experience that takes place in a country (France) that is anxiously and hesitantly facing diversity and multiculturalism.

\section{María Frías}

Born in Spain in a family half Andalusian and half German, I soon learned to walk that liminal state both at home and abroad. Following Zora Neale Hurston's advice: "You have to go there to know there," I have lived and taught in Ghana, where I went in search of the woman who was the protagonist of a research project. And so I did in Senegal, and in Peru. As I work with African emigrant women, serve as a volunteer at the local prison, and listen to nomadic and transnational stories about invented/ 
liquid borders, these African men and women teach me about their resilience and the need to look at the heartbreaking reality of a bloody Mediterranean Sea. My students learn about it, too.

\section{Andrea 0'Reilly Herrera}

I am the daughter and granddaughter of Cuban and Irish migrants. Acculturated primarily by our maternal Cuban relatives, we grew up fully conscious that we were members of a tight-knit diasporic community. Sensitive to the plight of others as a result of their experiences, my parents opened our home to an eclectic gathering of people from across the world; this included blood relatives, acquaintances, and even complete strangers, all of whom had left their native countries under some form of duress and consequently became part of our "extended" family. When I was a child, the world appeared as though it was without frontiers. Privy to passionate and oftentimes painful discussions regarding the adverse emotional and psychic conditions to which displaced peoples adapt and survive, my sense of identity was shaped indelibly by their stories. It wasn't until adulthood that I realized that my consciousness and my cultural imagination were supplanted, for they were based on an idea of a nation that was at once present and absent-a displaced nation of word and memory. The deep seeded sense of belonging to Cuba that was cultivated in us from earliest childhood accounted, in some sense, for the profound and perpetual sense of un-belonging that I-like others-experience, though we are not displaced in any literal sense. Caught in this conundrum, our lives have been defined by the paradoxical struggle of recuperating and eliminating space. This struggle, I suppose, is the legacy of colonialism, and the particular form of cosmopolitanism that has emerged in its shadow.

\section{Sheena Garrant}

Alain Leroy Locke's conceptualization of cultural pluralism and relativism as a philosophy that would lead society toward world peace echoes a vision of cosmopolitanism and unity that I sought growing up. My adoptive mother immigrated from Panama to the United States when she was 20 years old. My adoptive father, an upstate New Yorker, traveled the world through his service in the United States Navy. My hometown was small and primarily white, aside from my nuclear family. I experienced racism frequently and always felt like an outsider. Similarly, abused and neglected as a child by my adoptive parents, I became nomadic, traveling from state to state after my sixteenth birthday. Home was wherever I was, and I always viewed moving to different places, even if sleeping on park benches, and traveling as opportunities to grow and learn more about the world. I was also looking for a place to fit in. As an emotional and intellectual escape mechanism, I read voraciously as a child and teen. I read anything and everything and was reading adult books well before I was a teenager. My childhood and experiences as a teenager then gave me the capacity to inhabit various ways of being and seeing that the majority of my peers lacked. My frequent movement and mobility strengthened my intellectual and emotional intelligence in ways that 
inspire cosmopolitan inclinations and interpretations. However, I view cosmopolitanism as a sort of foundation for my movement "past" and through such philosophies to a conceptualization of the world that has more liberatory potential.

\section{Tingting Hui}

As to the question of my personal and academic trajectory in relation to cosmopolitanism, three years ago I moved to the Netherlands from China for my studies. This experience of a new strange language and culture unmoors me from my comfort zone, which incites self-doubt, but also invites reflection and reconstruction of my past and present. I have become quite engaged with the topic of hospitality and cosmopolitanism and with the pain and liberty of being a foreigner. In the end, who's not a foreigner-a foreigner to other people, to other systems, and even to oneself?

\section{Joanna Jasińska}

The source of my cosmopolitanism has been curiosity. Growing up in Poland, where almost everybody was Polish, white, and Catholic, I have always been attracted by people who looked, behaved, and thought differently. As a teenager, I hitchhiked all over Europe to see firsthand what the world looked like. Today I work in an international environment as a sociologist, a musician, and a linguist. My students come from all over the world, I do sociological research in Sicily, record my music in Canada, and have my radio program where I invite migrants who tell their life stories. Poland is still white and Catholic, but I have found my own place here.

\section{Raphaël Lambert}

Something strange happened to me twenty years ago. I moved to the United States to complete my education, and I became, overnight, a "privileged white man"-just like that! Born in a French village to a large family of modest means, the metamorphosis wasn't short of extraordinary. Today, I teach African American literature and culture in Japan, which makes me, no doubt, a cosmopolitan man. Or does it? Cosmopolitanism is neither a label nor a condition: It must be cultivated, like Voltaire's garden, and the best way to do so is by embracing the definition Victor Ségalen gave of diversity back in 1904: "Let us not flatter ourselves for assimilating the customs, races, nations and others who differ from us. On the contrary, let us rejoice in our inability ever to do so, for we thus retain the eternal pleasure of sensing Diversity." Ségalen synthesized this attitude through the figure of the exot, who "is a born Traveler, someone who senses all the flavor of diversity in worlds filled with wondrous diversities." When I become a genuine exot, I will feel genuinely privileged.

\section{Ewa Luczak}

I was exposed to the language of social justice, cross-ethnic and cross-racial solidarity, as well as a belief in transnational friendship as a child without knowing the term “cosmopolitanism." My mother, who as a teenager experienced WWII, taught me 
many hard lessons about the consequences of the discourses of political supremacy, tribalism, and exclusionism. She lived her simple post-WWII life without ever seeing another country, yet she inculcated in her children the value of openness and dialogue. When I left Poland for the first time as a twenty-year-old young woman to experience the life of a poor immigrant, it was only natural for me to fall back on what I learned at home. Later on, living on a different continent and meeting people coming from all walks of life and parts of the world and pursuing my studies of African American literature, I came to better understand the lesson taught by my mother. Now I continue to build on that, and recently in my research, I have turned towards the critique of one of the most divisive and exclusionary scientific discourses of the twentieth century-that of eugenics.

\section{Aparajita Nanda}

I understood "cosmopolitanism" from my mother, an eminent scholar, who did her Ph.D. at the London School of Economics right after World War II. She retired as Professor Emeritus, one of only six who were awarded the emeritus status in early 1970s India. In the late 1940s, when female education was just picking up in India, and higher studies for women was unheard of, she won a state scholarship and came to England to do her Ph.D. She embraced one and all, irrespective of caste, creed, or color, and brought me up to respect everyone as human beings, no matter what their religious faith may be or their economic standing. Today, I can say I am a "citizen of the world"- Indian by birth, US American by citizenship. I teach at the University of California, Berkeley, and Santa Clara University. I teach African American and Indian literature with the same passion and commitment. And as I tell my students: "If you have not felt the stories come alive, not felt them on your skin, you and I have never met."

\section{Kudzayi Ngara}

Born in rural, colonial Rhodesia (now Zimbabwe), I was the first black head-boy of my former whites-only primary school. I fell in love and disgust, in equal measure, with Dickens's London in high school and beyond. After enrolling for postgraduate studies and working in South Africa, I have had the opportunity to travel the world. The nodes and networks of traversal are fodder for my intellectual musings. I am cosmopolitan.

\section{Malin Pereira}

My mother was a cosmopolitan. Despite a narrow range of personal and career options available to her as a woman in the 1950s and 1960s US, coming from a small town in Kansas and having limited means, my mother moved to Washington, DC, after college and worked for a senator. She read widely, knew artists (some of whom became recognized figures in opera, painting, and modern dance), learned how to cook international foods, and mastered découpage. When I began studying African 
American literature it was the 1980s, the era of Henry Louis Gates, Jr., and Houston Baker. The foundations of the field were in the oral tradition and the music; moreover, the African American literary tradition was being conceived around how the texts were in conversation with other texts in the tradition. Because of my own background as well as a rather traditional (read: white US Americans and British) undergraduate education in English, I kept seeing other conversations black writers were having, conversations I eventually came to understand as cosmopolitan.

\section{Anna Pochmara}

My personal engagement with cosmopolitanism is directly linked to my academic experience. During a year in Berlin and a year in New Haven, I lived in multinational communities of immigrants and visiting scholars. Such experiences of foreign homes were shared by many Poles in the twenty-first century, especially after we joined the European Union. The increased mobility largely contributed to the rise of new patriotism, parallel to rooted cosmopolitanism. In the recent wave of pro-democratic protests in Poland, people in the streets bore Polish national flags and flags of the European Union. Many Poles have formed a multilayered, rooted cosmopolitan identity that combines their local histories with the global, though mostly white European intracontinental, context.

\section{Anna Sosnowska}

When I was in my twenties, I discovered cosmopolitanism as a thrilling mystery that should be understood. Studying in New York City, and visiting European cities for scholarships, conferences, summer schools, and tourist stays, made me curious, excited, and hungry for more. Complicated layers of history, changing boundaries, multiple legacies of places full of immigrants and students from around the world seemed a perfect environment for an aspiring intellectual. Now in my forties, married to a foreigner, raising bilingual and bicultural children, and having parents-in-law and numerous cousins-in-law coming from another culture, I see cosmopolitanism as an everyday life task that requires effort. Cultural difference remains a mystery to be understood but can be a source of frustration, boredom, and exhaustion. When visiting the same and new cosmopolitan cities in the United States and Europe, I see them now as scenes of unprecedented social experiment and immigrants-as heroes.

\section{Annarita Taronna}

My personal experiences and views on cosmopolitanism are closely related to the practice of translation that I have been theorizing and experimenting with since my undergraduate degree in Modern Languages and Literatures. Since then, translating from Catalan, Chicano, and African American English into Italian has led me to outline extraordinary accounts of linguistic and cultural cosmopolitanism as openness to a world in which citizenship is decoupled from its national bearings and boundaries. This idea is obsessively part of the fabric of my everyday life as a southern Italian 
citizen, translator, and academic living on the Mediterranean cosmopolitan borders of Apulia, expressing hostility towards the closure of borders and denial of rights to non-European-nationals, and showing hospitality towards the unstoppable flows of people and bodies.

\section{Santiago Vaquera-Vásquez}

My connection to cosmopolitanism is both personal and scholarly. Growing up in the fissure between Mexico and the United States, my life has always been about crossing borders. Having lived and spent much time in cities like San Francisco, Mexico City, Madrid, Barcelona, and Istanbul, cosmopolitan migrant flows have always been on my mind. For me, Gloria Anzaldúa’s dictum to "be a crossroads" when you live in the borderlands - wherever those contact zones may be- is fundamental to my writing, research, and teaching: It is by positioning oneself at the crossroads, as difficult as that can be, that I seek to engage my classes to understand and hopefully accept the possibilities inherent in being, as Rubén Martínez once wrote, both "North and South in the North and in the South."

\section{Hanna Wallinger}

My personal background as the daughter of parents who were both dislocated after World War II has contributed to my interest in migration studies and cosmopolitanism. My seminars on migration narratives have shown to me that this topic is more than important for the present generation of students and scholars and that the teaching of and writing about transnationalism/cosmopolitanism/mobility and immobility are relevant in discussions about nation, migration, and home.

\section{Marta Werbanowska}

Living at the crossroads of Polish and North American geographies and cultures, I inhabit a version of the cosmopolitan experience-and the opportunities as well as the challenges that come with it-in my daily life. I see cosmopolitan nomadic consciousness as a promising political and ethical standpoint from which to approach the increasingly difficult questions of human and nonhuman relationality at all levels, from the intimately personal to the globally inter-communal.

\section{Melanie Masterton Sherazi}

Reading William Demby's transnational fiction, with its meditations on national and global belonging, drew me into the orbit of post-WWII Italy's artistic communities. Having lived my life in Los Angeles, the daughter of a Scottish immigrant father and with family in Scotland, Mexico, Canada, and Pakistan, I privilege boundary crossings and affiliative connections in my work. 


\section{Joanna Ziarkowska}

My maternal grandfather's WWII history-an experience of dislocation, forced adaptation to a new environment, and a long-awaited return home-quickly made me aware of the complexity of concepts such as "home," "border," and "movement." While undeniably traumatic, his experience of forced dislocation was also one of making friends and learning the skill of cultural translation. Many years after hearing his war story for the first time, I am tracing transnational and transindigenous motifs in Native American literature and I am moved, again, by how stories of leaving home, travel, migration, and cultural survival become part of debates on the multiple forms and manifestations of contemporary cosmopolitanism. 